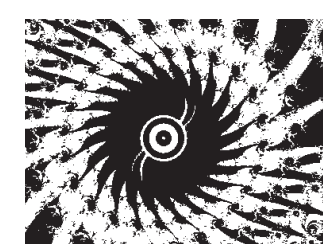

doi: $10.5559 /$ di.21.4.08

\title{
ODNOS EMOCIONALNE KOMPETENTNOSTI I PREPOZNAVANJA EMOCIJA U GLAZBI
}

Snježana DOBROTA, Ina REIĆ ERCEGOVAC Filozofski fakultet, Split

UDK: 159.942.5:78

Izvorni znanstveni rad

Primljeno: 4. 9. 2012.

Cili je ovog rada bio istražiti odnos između prepoznavanja emocija u glazbi i rezultata na standardnim mjerama emocionalne kompetentnosti. $U$ istraživanju je sudjelovalo 329 studenata, koji su najprije ispunili Upitnik emocionalne kompetentnosti (Takšić, 2002.), a zatim i Upitnik za procjenu glazbenih ulomaka tijekom slušanja šest ulomaka klasične glazbe različita emocionalnog ugođaja. Zadatak sudionika bio je navesti dominantnu emociju koju su prepoznali u glazbenom ulomku te označiti je li im glazbeni ulomak poznat otprije. Rezultati su pokazali da poznatost glazbenih ulomaka uglavnom nije utjecala na prepoznavanje emocija u glazbi, a sudionici su s najvećom točnosti prepoznali emociju sreće, zatim tuge, a s najmanjom točnosti emociju straha. Potvrđena je i glavna pretpostavka istraživanja o odnosu prepoznavanja emocija u glazbi i rezultata na Upitniku emocionalne kompetentnosti, pri čemu je utvrđeno da sudionici koji su iskazali veću točnost prepoznavanja emocija u glazbi postižu i više rezultate na Upitniku emocionalne kompetentnosti, posebno na podskali sposobnosti razumijevanja i uočavanja emocija, gdje je utvrđena značajna razlika u prepoznavanju svih triju osnovnih emocija iz glazbe. Značajne su korelacije dobivene između rezultata svih podskala Upitnika emocionalne kompetentnosti i sposobnosti prepoznavanja emocija u glazbi, osim povezanosti između sposobnosti upravljanja i regulacije emocija i sposobnosti prepoznavanja tuge u glazbi.

Ključne riječi: emocije, emocionalna kompetentnost, glazba

Snježana Dobrota, Sveučilište u Splitu, Filozofski fakultet, Put iza nove bolnice 10c, 21000 Split, Hrvatska.

E-mail: dobrota@ffst.hr 
Emocije su doživljaji koji se sastoje od niza povezanih reakcija na određeni događaj ili situaciju, a prema složenosti afektivnih stanja zauzimaju drugo mjesto, nakon preferencija (Scherer, 2000.). Preferencije kao najjednostavnija afektivna reakcija uključuju evaluativne prosudbe o podražaju u obliku sviđanja - nesviđanja, dok emocije uključuju relativno krat$\mathrm{ku}$, ali $\mathrm{u}$ odnosu na preferencije intenzivniju, sinkroniziranu reakciju organizma na vanjski ili unutarnji podražaj koji je za pojedinca važan. Osnovna obilježja emocija odnose se na fiziološke promjene, subjektivni doživljaj te emocionalnu ekspresiju. Facijalna ekspresija emocija najčešća je $u$ istraživanjima sposobnosti prepoznavanja emocija na svim dobnim skupinama, a osjetno su se rjeđe $u$ istraživanjima prepoznavanja emocija rabili auditivni podražaji ili glazba. Istraživanja prepoznavanja facijalnih ekspresija emocija pokazala su da je sposobnost prepoznavanja emocija povezana s nekim značajkama ličnosti, poput samomotrenja, lokusa kontrole ili empatije. Od osobina ličnosti iz petofaktorskoga modela, pokazalo se da su otvorenost za nova iskustva, a u nešto manjoj mjeri i savjesnost te ekstraverzija, prediktivne za uspješnije prepoznavanje emocija, dok je neuroticizam povezan s lošijim prepoznavanjem emocija (Matsumoto i sur., 2000.). Unatoč nekim individualnim varijacijama u sposobnosti prepoznavanja emocija, Keltner i Ekman (2003.) navode da je prepoznavanje emocija facijalnom ekspresijom, zvukom ili glazbom uglavnom univerzalno. Istraživanja na dojenčadi pokazala su da već u najranijoj dobi čovjek ima sposobnost razlikovanja emocija, što sugerira biološku spremnost za diskriminaciju socijalno relevantnih podražaja iz okoline (Nawrot, 2003.). To se odnosi na temeljne emocije koje su "naslijeđeni uzorci odgovora na pojedine tipove podražaja i izražavaju se kroz veliki broj tjelesnih reakcija, a posebno facijalnu ekspresiju" (Kardum i Gračanin, 2004., 278). Sposobnost prepoznavanja emocija dio je emocionalne inteligencije, koja prema modelu Mayera i Saloveya (1997.) uključuje sposobnost brzoga zapažanja, procjene i izražavanja emocija, sposobnost uviđanja i generiranja emocija koje olakšavaju mišljenje, sposobnost razumijevanja emocija i znanje o emocijama te sposobnost reguliranja emocija u svrhu promocije emocionalnog i intelektualnog razvoja. Percepcija emocija najjednostavnija je emocionalna sposobnost kojom pojedinac zapaža koje se emocije kriju iza nečijega fizičkog stanja, osjećaja i razmišljanja. Ta se sposobnost odnosi na zapažanje vlastitih emocija, ali i na percepciju emocija drugih osoba te prepoznavanje emocija u umjetničkim djelima i drugim živim i neživim objektima iz okoline. Sposobnost razumijevanja emocija odnosi se na uoča- 
DRUŠ. ISTRAŽ. ZAGREB GOD. 21 (2012),

BR. 4 (118),

STR. $969-988$

DOBROTA, S REIĆ ERCEGÓVAC, I.: ODNOS.. vanje zakonitosti pojavljivanja određenih emocija te općenito emocionalno znanje, što znači da pojedinac zna koje su emocije slične, kakvi su odnosi među emocijama te što izaziva određene emocije. Sposobnost regulacije i upravljanja emocijama znači najsloženiju razinu emocionalne inteligencije, a temelji se na mogućnosti prepoznavanja i osvješćivanja vlastitih emocija te emocionalnoga znanja. Ova je emocionalna sposobnost odrednica emocionalne zrelosti, a svrha joj je emocionalni i intelektualni razvoj te socijalna adaptacija.

\section{Induciranje emocija glazbom}

Odnos emocija i glazbe vrlo je složen, pa ne iznenađuje mnogo kontradiktornosti u svakom segmentu odnosa emocija i glazbe na koje upućuju Juslin i Västfjäll (2008.). Treba prije svega razlikovati emocije koje se glazbom izražavaju i prenose od emocija koje je glazbom moguće potaknuti kod slušatelja. Glazba ima brojne funkcije u životu pojedinca, pa i među emocionalnima, gdje je ona medij kojim pojedinci mogu regulirati vlastito raspoloženje (Rentfrow i Gosling, 2003.). Višestruke su uloge glazbe. Tako pojedinci mogu uz pomoć glazbe mijenjati emocije, izražavati emocije, zabavljati se, utješiti ili smanjiti stres (Juslin i Laukka, 2004.; Sloboda i sur., 2001.). Neki autori slažu se kako glazba može kod slušatelja potaknuti emocije (Koelsch, 2005.; Panksepp i Bernatzky, 2002.), dok neki smatraju da to nije moguće (Scherer, 2003.). Neki pak autori razlikuju osnovne emocije proizašle iz uglavnom psihologijskih teorija i neke specifične emocije vezane uz glazbu, pa bi upravo ove potonje bile one koje se mogu inducirati kod slušatelja glazbe (Scherer i Zentner, 2001.). Ipak, ni vrste tih emocija ni putovi, odnosno mehanizmi kojima bi se inducirale takve emocije, nisu još ni sasvim razjašnjeni, a ni empirijski dovoljno potvrđeni.

Juslin i Västfjäll (2008.) predlažu nekoliko mehanizama koji sudjeluju u induciranju glazbenih emocija a nisu međusobno isključivi nego komplementarni. Mogu se promatrati kao alati za obradbu informacija na raznim mozgovnim razinama. U području glazbenog očekivanja, kao jednog od tih mehanizama, ističe se rad Meyera (1956., prema Vink, 2001.), koji navodi da postoje razni elementi glazbe (promjene melodijske linije, ritma i sl.) koji utječu na očekivanja slušatelja prilikom slušanja nekoga glazbenog djela, a upravo su ta očekivanja odrednice doživljaja emocija u glazbi. Jedna od implikacija njegove teorije jest da slušatelj laik prije svega emocionalno reagira na glazbu, dok školovani glazbenici reagiraju uglavnom kognitivno na slušanje glazbe (Jansma i de Vries, 1995.). Mandler (1984.), na primjer, u svojoj kognitivnoj teoriji navodi da je pobuđenost (arousal) preduvjet za emocional- 
DRUŠ. ISTRAŽ. ZAGREB GOD. 21 (2012) BR. $4(118)$

STR. $969-988$

DOBROTA, S REIĆ ERCEGÓVAC, I. ODNOS.. ni doživljaj, ali manju važnost pridaje samoj pobuđenosti. Berlyne (1974.) navodi da prilikom slušanja glazbe slušatelj uzima u obzir poznatost i složenost glazbe, na temelju čega pojedinci doživljavaju glazbu ugodnom, pa je hedonistička vrijednost glazbe niska kada slušamo nešto sasvim nepoznato.

Doprinos raspravama o odnosu emocija i glazbe, odnosno mogućnosti poticanja emocija slušanjem glazbe, pružili su rezultati istraživanja o utjecaju glazbe na autonomni živčani sustav. Povezanost fizioloških reakcija organizma i slušanja glazbe dobro je dokumentirana istraživanjima (Dillman Carpentier i Potter, 2007.; Krumhansl, 1997.; Nyklicek i sur., 1997.), koja su potvrdila pretpostavku da glazba utječe na rad autonomnoga živčanog sustava, pa bi se moglo govoriti i o empirijskom doprinosu pretpostavci o induciranju emocija kod slušatelja. Metaanaliza eksperimenata u kojima se istraživao utjecaj glazbe na fiziološke indikatore aktivacije (Pelletier, 2004.) pokazala je da opuštajuća glazba djeluje na smanjenje pobuđenosti i aktivacije, no veličina je toga efekta varirala s obzirom na dob, glazbene preferencije, stresore i ranija glazbena iskustva sudionika. Dillman Carpentier i Potter (2007.) ispitivali su efekte raznih glazbenih stilova na razinu simpatičke aktivacije sudionika te su pokazali da slušanje glazbe brzih ritmova povećava aktivaciju, što nije utvrđeno za glazbu sporih ritmova. Nadalje se pokazalo da stil i tempo glazbe imaju značajan interakcijski učinak na elektrodermalnu reakciju sudionika, i to tako da pri slušanju klasične glazbe brzi tempo povećava aktivaciju, dok takav tempo ima suprotan učinak na aktivaciju sudionika pri slušanju rock-glazbe. Krumhansl je (1997.) utvrdila značajne promjene $u$ fiziološkim parametrima sudionika prilikom slušanja glazbe $u$ odnosu na periode mirovanja, pri čemu se slušanje glazbenih ulomaka različite emocionalne obojenosti manifestiralo specifičnim promjenama fizioloških parametara - tužni ulomci potaknuli su značajne promjene $u$ srčanom ritmu, krvnom tlaku, elektrodermalnoj reakciji i tjelesnoj temperaturi. Ulomci čija je dominantna emocija bila strah potaknuli su promjene $u$ amplitudi i frekvenciji pulsa, a veseli ulomci utjecali su na promjene u obrascima respiracije.

Veza između percepcije emocija u glazbi i doživljavanja istih emocija nije potpuna, pa slušatelj može prepoznati neku emociju u glazbi, a da je sam ne doživljava. Ipak, Evans i Schubert (2008.) navode da u većini slučajeva postoji slaganje između emocija koje slušatelj percipira u glazbi i koje sam doživljava, što podržava jednu od hipoteza o mehanizmima koji sudjeluju u induciranju emocija, i to onu o emocionalnom prelijevanju (Juslin i Västfjäll, 2008.). 


\section{Prepoznavanje emocija u glazbi}

Veliki doprinos opisivanju i istraživanju prepoznavanja glazbenih emocija dala je autorica Hevner još tridesetih godina 20. stoljeća, izvodeći ispitanicima glazbu na klaviru, i to u originalnoj i adaptiranoj verziji, mijenjajući samo jedan od glazbenih elemenata u svakoj izvedbi. Njezini su rezultati pokazali da od glazbenih odrednica tempo i tonalitet najviše utječu na slušatelja, pri čemu se glazba u duru, brzoga tempa, opisivala kao vesela, a glazba sporoga tempa i u molu kao osjećajna (prema Vink, 2001.). I druga su istraživanja potvrdila da se za glazbene ulomke u duru obično vezuje emocija sreće, a one u molu emocija tuge (Peretz i sur., 1998.).

Glazbom je stoga najlakše prenositi upravo osnovne emocije - sreće i tuge - jer se to ostvaruje variranjem osnovnih glazbenih odrednica, poput tempa i tonaliteta (Krumhansl, 1997.), a upravo se za emocije tuge i sreće pokazalo da ih sudionici najlakše percipiraju i prepoznaju u glazbi u odnosu na druge, poput ljutnje ili iznenađenja (Mohn i sur., 2011.). Sreća je, osim u glazbi (Gosselin i sur., 2011.), najlakše prepoznatljiva emocija i u facijalnoj ekspresiji (Gašpar i sur., 2011.), a najtežom za prepoznavanje u glazbi pokazala se emocija iznenađenja (Gašpar i sur., 2011.). Osim toga, istraživanja na raznim dobnim skupinama pokazala su da je prepoznavanje sreće u glazbi konstantno u svim dobnim skupinama, dok prepoznavanje tuge i straha ovisi o dobi slušatelja, pri čemu je starija dob povezana s manjom sposobnosti prepoznavanja tuge i straha (Lima i Castro, 2011.). Iako neki autori navode da je emocije straha i ljutnje u glazbi vrlo teško razlikovati (Nawrot, 2003.; Robazza i sur., 1994.), neka su istraživanja pokazala da ljudi mogu percipirati i sasvim male razlike $u$ emocijama $u$ glazbi. Tako su Zammuner i Petitbon (2006.) utvrdili da ljudi uspješno razlikuju emocije u glazbi koje su najsličnije prema glazbenim značajkama (tempo, glasnoća i sl.), kakve su na primjer nježnost i tuga (Juslin i Sloboda, 2001.) ili strah i ljutnja (Laukka i Gabrielsson, 2000.).

Posebno zanimljivima čine se istraživanja provedena na kliničkim i kontrolnim uzorcima sudionika kojima je cilj bio anatomski i funkcionalno povezati neka mozgovna područja s prepoznavanjem emocija u glazbi. Rezultati tih istraživanja pokazali su postojanje gusto povezane mreže mozgovnih struktura koje ih vezuju s prepoznavanjem emocija u glazbi (Dolan, 2007.). Ta mreža uključuje veliko bilateralno područje insule, orbitofrontalnoga korteksa, prednje cingularne vijuge, središnjega prefrontalnog korteksa, prednjega temporalnog i parietalnog korteksa, amigdale i ostalih limbičkih struktura te striatuma (Omar i sur., 2011.). Upravo ovakva istraživanja pružila su dokaze o sličnosti mehanizama koji su u osnovi pre- 
DRUŠ. ISTRAŽ. ZAGREB GOD. 21 (2012)

BR. 4 (118)

STR. $969-988$

DOBROTA, $S$ REIĆ ERCEGÓVAC, I. ODNOS.. poznavanja emocija iz različitih modaliteta. Naime, rezultati istraživanja pokazuju kako su mozgovna područja povezana s prepoznavanjem emocija $u$ glazbi ista kao i kod facijalne ekspresije (Omar i sur., 2011.), pa se može govoriti i o krosmodalnom sustavu za procesiranje emocionalnih informacija (Lantz i sur., 2003.). Na primjer, istraživanja pokazuju kako je oštećenje lateralnoga orbitofrontalnog korteksa i prednje insule povezano s lošijim prepoznavanjem emocija i iz facijalne ekspresije i iz glazbe (Omar i sur., 2011.). Ipak, Dolan (2007.) navodi da je oštećenje amigdale povezano s lošijim prepoznavanjem emocija samo iz glazbe, uz očuvano prepoznavanje emocija na temelju facijalne ekspresije. Autor zaključuje o vecoj ovisnosti o pobudljivosti (arousalu) kada se radi o kodiranju glazbenih emocija nego što je to kod emocionalnih informacija iz drugih izvora (Dolan, 2007.). Amigdala se pokazala zanimljivom i kada je riječ o prepoznavanju emocije straha $u$ glazbi. Naime, u nizu istraživanja u kojima je upotrijebljena razna metodologija pokazalo se da je amigdala povezana s procesiranjem emocije straha, bez obzira na modalitet (vizualni ili auditivni podražaji) (prema Gosselin i sur., 2011.).

$S$ druge strane, neka istraživanja nisu potvrdila povezanost $\mathrm{u}$ sposobnosti prepoznavanja emocija kada je riječ o raznim modalitetima. Tako su Roberts i sur. (2006.) dobili slabu povezanost između prepoznavanja emocija na temelju facijalne ekspresije i zvuka $(\mathrm{r}=0,22)$, kao i MacCann i sur. (2011.) $(\mathrm{r}=0,03)$, čak i kada su analizirali povezanost unutar iste emocije.

Neka su istraživanja pokušala utvrditi prediktore koji bi objasnili individualne razlike upravo u sposobnosti emocionalne osjetljivosti i recepciji emocionalnih informacija u glazbi. Juslin (1997.) navodi da glazbeno obrazovanje uglavnom ne utječe na sposobnost slušatelja da prepozna određene emocije u glazbi te ističe mogućnost da se radi o široj sposobnosti prepoznavanja emocija, odnosno o aspektu emocionalne inteligencije. Tu su pretpostavku potvrdili i Trimmer i Cuddy (2008.), koji su utvrdili značajnu prediktivnu vrijednost emocionalne inteligencije $u$ identificiranju emocija $u$ glazbi (i govoru), za razliku od glazbenog obrazovanja, koje se nije pokazalo prediktivnim. Resnicow i sur. (2004.) također su upozorili na značajnu povezanost prepoznavanja emocija u glazbi i emocionalne inteligencije $(r=0,54, p<0,05)$. Mohn i sur. (2011.) testirali su sposobnost prepoznavanja šest osnovnih emocija u glazbi, pri čemu također nisu utvrdili povezanost između prepoznavanja emocija u glazbi i glazbenog obrazovanja, ali ni između prepoznavanja emocija u glazbi i osobina ličnosti iz petofaktorskoga modela. U pokušaju objašnjenja koji su aspekti percepcije glazbe univerzalni, a koji stečeni iskustvom slušanja 
DRUŠ. ISTRAŽ. ZAGREB GOD. 21 (2012), BR. 4 (118),

STR. 969-988

DOBROTA, S. REIĆ ERCEGÓVAC, I. ODNOS..

$\rightarrow$ SLIKA 1

Model redundantnosti znakova u percepciii emocija u glazbi (Balkwill i Thompson, 1999., 46) glazbe određene kulture, provedeno je interkulturno istraživanje, rezultati kojega su između ostaloga pokazali da je prepoznavanje triju osnovnih emocija u glazbi zapadnjačke kulture univerzalno (Fritz i sur., 2009.). Istraživanja provedena na ljudima sa stečenom amuzijom pokazala su da oni mogu točno percipirati emocionalni kontekst glazbe unatoč ozbiljnim poteškoćama u sposobnosti zamjećivanja raznih značajki melodija i složenih ritmičkih odnosa (Lantz i sur., 2003.).

Balkwill i Thompson (1999.) proveli su istraživanje kako bi utvrdili utječu li akustičke dimenzije indijske glazbe, poput tempa i melodijske složenosti, na procjene emocija u glazbi. Pod pojmom akustičkih idioma autori razumijevaju osobine akustičkih signala koji se mogu percipirati i interpretirati bez eksplicitnoga ili implicitnog poznavanja glazbenih konvencija. Takvi se idiomi mogu interpretirati u glazbi svih kultura, za razliku od onih kulturno specifičnih, koji se odnose na poznavanje glazbenih konvencija određene kulture. Slijedom toga, autori su koncipirali model percepcije emocija u glazbi pod nazivom Model redundantnosti znakova u percepciji emocija u glazbi (Slika 1), koji polazi od pretpostavke da slušatelji mogu procjenjivati afektivne značajke nepoznate glazbe percipiranjem njezinih akustičkih idioma. Međutim, budući da se emocije izražavaju kulturno-specifičnim i akustičkim idiomima, dolazi do redundancije, pa tako što je veći broj glazbenih idioma, bez obzira na to bili oni kulturno-specifični ili akustički, snažnija je ekspresija emocija.

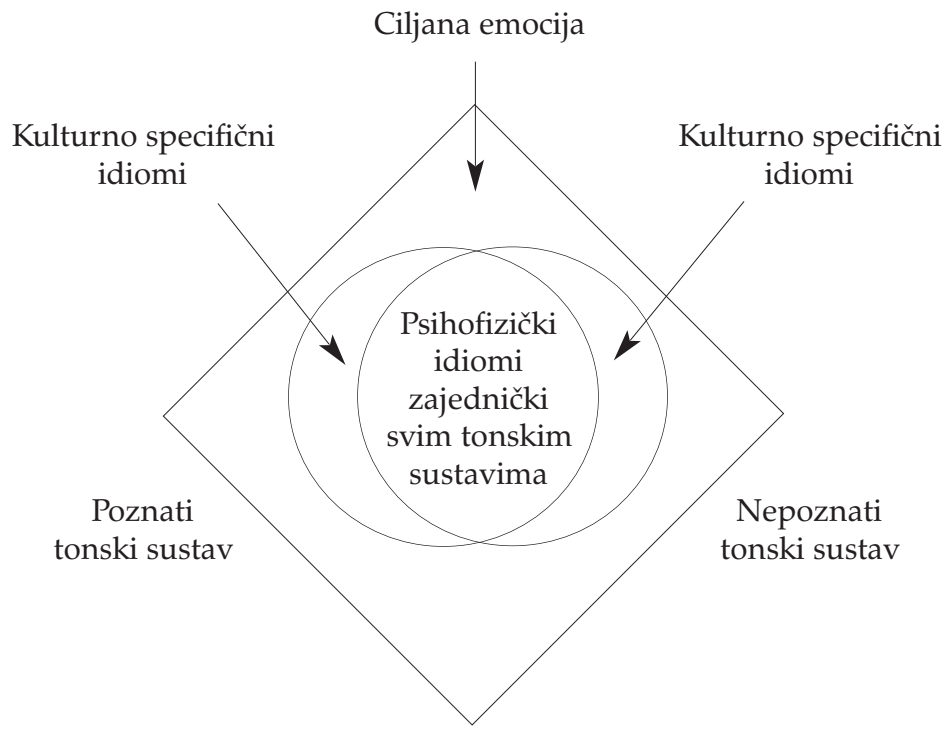


DRUŠ. ISTRAŽ. ZAGREB GOD. 21 (2012), BR. 4 (118)

STR. 969-988

DOBROTA, S., REIĆ ERCEGÓVAC, I. ODNOS.

\section{METODA}

Sudionici

\section{Instrumenti}

Cilj je ovoga rada ispitati pretpostavku o značajnoj povezanosti između sposobnosti prepoznavanja emocija u glazbi i određenih aspekata emocionalne inteligencije. Vodeći se rezultatima nekih ranijih istraživanja koja su sugerirala da je sposobnost prepoznavanja emocija u glazbi jedan od aspekata emocionalne inteligencije (Juslin, 1997.; Gabrielsson i Juslin, 2003.), valja pretpostaviti da će pojedinci veće emocionalne kompetentnosti biti uspješniji u prepoznavanju dominantne emocije glazbenih ulomaka klasične glazbe. U skladu s tim, formulirani su sljedeći problemi na koje se željelo odgovoriti istraživanjem:

1. ispitati postoje li razlike $\mathrm{u}$ točnosti prepoznavanja glavne emocije glazbenog ulomka s obzirom na njegovo poznavanje

2. ispitati razlikuju li se sudionici u točnosti prepoznavanja emocija sreće, tuge i straha u glazbi

3. ispitati postoje li razlike $\mathrm{u}$ emocionalnoj kompetentnosti sudionika s obzirom na točnost prepoznavanja glavne emocije glazbenog ulomka

4. ispitati povezanost između točnosti prepoznavanja emocija u glazbi te tri aspekta emocionalne kompetentnosti (uočavanje i razumijevanje emocija, imenovanje i izražavanje emocija te sposobnost upravljanja i regulacije emocija).

Ispitivanje je provedeno na uzroku od 329 studentica Filozofskoga fakulteta Sveučilišta u Splitu. Sudionice su bile studentice prve $(\mathrm{N}=123)$, druge $(\mathrm{N}=69)$, treće $(\mathrm{N}=52)$, četvrte $(\mathrm{N}=47)$ i pete $(\mathrm{N}=38)$ godine s nekoliko odsjeka.

Za potrebe istraživanja pripremljen je glazbeni nosač zvuka koji sadrži šest instrumentalnih glazbenih ulomaka (Tablica 1), svaki u trajanju otprilike od jedne minute, od kojih dva predstavljaju emociju tuge, dva straha i dva sreće (prema Krumhansl, 1997.). Glazbeni ulomci koji predstavljaju emociju tuge bili su u polaganom tempu, u molu, s prilično konstantnim rasponom visine i dinamike. Ulomci koji predstavljaju emociju straha bili su u brzom tempu, s disonantnim harmonijama i velikim varijacijama dinamike i visine. Sretni ulomci bili su u relativno brzom tempu, u duru, plesnih ritmova i relativno konstantnog opsega visine i dinamike. 
$\rightarrow$ TABLICA 1

Glazbeni primieri zvučnom upitniku

(1) TABLICA 2

Psihometrijske značajke podskala Upitnika emocionalne kompetentnosti

\begin{tabular}{ll}
\hline Glazbeni primjeri & Emocija \\
\hline Tomaso Albinoni: Adagio u g-molu za gudače i orkestar & tuga \\
Antonio Vivaldi: Proljeće (Četiri godišnja doba) & sreća \\
Gustav Holst: Mars - Glasnik rata (Planeti) & strah \\
Hugo Alfvén: Midsommarvaka & sreća \\
Modest Petrovič Musorgski: Noć na pustoj gori & strah \\
Samuel Barber: Adagio za gudače, op. 11 & tuga
\end{tabular}

Upitnik za procjenu glazbenih ulomaka konstruiran je za potrebe ovog istraživanja, a sastojao se od rednoga broja glazbenog ulomka, polja u koje su sudionici upisivali je li im ulomak poznat otprije ili ne te polja u koje su sudionici upisivali emociju prepoznatu u glazbenom ulomku.

Upitnik emocionalne kompetentnosti (UEK-45, Takšić, 2002.), koji je primijenjen $u$ ovom istraživanju, skraćena je verzija Upitnika emocionalne inteligencije istog autora, a nastao je na temelju modela Mayera i Saloveya (1997.). Upitnik se sastoji od 45 čestica raspoređenih u tri podskale - sposobnost uočavanja i razumijevanja emocija koja se sastoji od 15 čestica, sposobnost izražavanja i imenovanja emocija koja se sastoji od 14 čestica te podskala sposobnosti upravljanja i reguliranja emocija koja se sastoji od 16 čestica. Zadatak sudionika bio je da na skali Likertova tipa od pet stupnjeva procijeni koliko se svaka od tvrdnji odnosi na njega. Rezultati se formiraju po podskalama, kao linearne kombinacije procjena čestica koje čine pojedinu podskalu. Najveća je pouzdanost dobivena za podskalu uočavanja i razumijevanja emocija (Cronbach $\alpha=0,88$ ), što je u skladu s ranijim istraživanjima, $\mathrm{u}$ kojima je također ta podskala pokazala najveću pouzdanost, a koeficijenti su se kretali od 0,82 do 0,88 (Takšić i sur., 2006.). Podskala imenovanja i izražavanja emocija u ovom je istraživanju imala pouzdanost od Cronbach $\alpha=0,84$, što je nešto više od uobičajene pouzdanosti u ranijim istraživanjima (Takšić i sur., 2006.), dok je najniža pouzdanost za podskalu sposobnosti upravljanja i regulacije emocija (Cronbach $\alpha=0,70$ ), što je u skladu s navedenim pouzdanostima u ranijim istraživanjima ( 0,68 do 0,72 , prema Takšić i sur., 2006.). Prosječne vrijednosti i ostali pokazatelji podskala dobiveni primjenom u ovom istraživanju prikazani su u Tablici 2.

\begin{tabular}{lrrrrr}
\hline & & $\begin{array}{r}\text { Raspon } \\
\text { Podskale UEK-45 }\end{array}$ & M (SD) & $\begin{array}{r}\text { Korelacija } \\
\text { rezultata }\end{array}$ & $\begin{array}{r}\text { Cron- } \\
\text { crestica } \\
\text { bach } \alpha\end{array}$ \\
\hline česticama
\end{tabular}




\section{Postupak}

(1) TABLICA 3

Frekvencije poznatosti glazbenih ulomaka $\mathrm{i}$ točnih odgovora s obzirom na dominantnu emociju glazbenoga primjera $(\mathrm{N}=329)$
Ispitivanje je provedeno od 4. do 21. lipnja 2012. godine, $\mathrm{u}$ fakultetskim prostorijama - učionicama prema unaprijed dogovorenom rasporedu. Ispitivanje je bilo skupno, a u jednoj je skupini prosječno bilo 30 -ak sudionika. Sudionicima je ukratko objašnjena svrha provođenja istraživanja, zajamčena im je anonimnost te su zamoljeni da iskreno i precizno odgovaraju na pitanja. Svi su sudionici najprije ispunjavali Upitnik emocionalne kompetentnosti, nakon čega su upućeni u način provođenja glazbenoga dijela ispitivanja. Pri tome im nije rečeno o kojim se glazbenim ulomcima radi. Zadatak sudionika bio je da nakon odslušanoga glazbenog ulomka upišu je li im ulomak poznat otprije te da navedu dominantnu emociju koju su prepoznali tijekom slušanja svakoga glazbenog ulomka. Slijed slušanja glazbenih primjera varirao je od skupine do skupine, kako bi se raspodijelio utjecaj navikavanja i međusobnog uspoređivanja glazbenih ulomaka.

U obradbi prikupljenih podataka najprije su odgovori sudionika o emociji koju su naveli kodirani tako da su sudionici koji su naveli točnu emociju dobili 1 bod, a oni koji su naveli pogrešnu emociju 0 bodova. Pri tome je kriterij za bodovanje bio sljedeći: za glazbene ulomke koji su predstavljali dominantnu emociju tuge 1 bod dobili su sudionici koji su naveli tuga, sjeta, melankolija, žalost ili neki srodan pojam, dok su se pogrešnim odgovorima smatrali pojmovi koji predstavljaju druge emocije (npr. ljutnja, strah, opuštenost) ili pojmovi koji uopće ne predstavljaju emociju nego neku drugu značajku (npr. tišina, sporost). Točnim odgovorom za glazbene ulomke koji su predstavljali emociju sreće bodovali su se odgovori sreća, radost, veselje i sl., dok su se točnim odgovorom za glazbene ulomke koji predstavljaju emociju straha smatrali pojmovi strah, prestrašenost, uznemirenost, panika i sl. Bodovanje ovog upitnika obavili su zajednički stručnjak za glazbu i stručnjak za psihologiju.

Frekvencije poznatosti glazbenih ulomaka te točno navedenih emocija za svih šest glazbenih primjera prikazane su u Tablici 3.

\begin{tabular}{|c|c|c|c|c|}
\hline \multirow[b]{2}{*}{ Glazbeni primjeri } & \multicolumn{2}{|r|}{$\begin{array}{r}\text { Frekvencije } \\
\text { poznatosti }\end{array}$} & \multicolumn{2}{|c|}{$\begin{array}{r}\text { Frekvencije } \\
\text { točnih odgovora } \\
\end{array}$} \\
\hline & Poznato & Nepoznato & Točno & Netočno \\
\hline Tomaso Albinoni: Adagio u g-molu za gudače i orkestar & 119 & 210 & 231 & 98 \\
\hline Antonio Vivaldi: Proljeće (Četiri godišnja doba) & 328 & 1 & 231 & 98 \\
\hline Gustav Holst: Mars - Glasnik rata (Planeti) & 46 & 283 & 168 & 161 \\
\hline Hugo Alfvén: Midsommarvaka & 133 & 196 & 194 & 135 \\
\hline Modest Petrovič Musorgski: Noć na pustoj gori & 132 & 197 & 192 & 137 \\
\hline Samuel Barber: Adagio za gudače, op. 11 & 123 & 206 & 180 & 149 \\
\hline
\end{tabular}


DRUŠ. ISTRAŽ. ZAGREB GOD. 21 (2012), BR. 4 (118),

STR. 969-988

DOBROTA, S. REIĆ ERCEGÓVAC, I.: ODNOS..

\section{REZULTATI}

Korelacije među odgovorima za glazbene primjere koji predstavljaju istu emociju relativno su niske, no ipak značajne ( $\mathrm{rsreća}=0,30$; rtuga $=0,27 ; \mathrm{r}$ strah $=0,22$ ). Osim toga, glazbeni primjeri koji su predstavljali istu emociju imali su jednake osnovne glazbene značajke - tempo i tonalitet - pa je za svaku emociju izračunan ukupan rezultat kao suma odgovora dvaju glazbenih primjera iste dominantne emocije. Tako su sudionici za svaku emociju mogli postići rezultat 0,1 ili 2 .

Kako bi se odgovorilo na prvi problem istraživanja te ispitao utjecaj poznatosti glazbenih primjera na točnost prepoznavanja glavne emocije u njima, provedeno je niz Man-Whitneyevih U-testova, kojima je testirana razlika u točnosti odgovora s obzirom na (ne)poznavanje pojedinoga glazbenog primjera. Rezultati tih testova prikazani su u Tablici 4.

\begin{tabular}{lrrr}
\hline Glazbeni primjeri & $\mathrm{U}$ & $\mathrm{z}$ & $\mathrm{p}$ \\
\hline Tomaso Albinoni: Adagio u g-molu za gudače i orkestar & 11928,00 & $-0,86$ & 0,39 \\
Antonio Vivaldi: Proljeće (Četiri godišnja doba) & - & - & - \\
Gustav Holst: Mars - Glasnik rata (Planeti) & 5606,00 & 1,74 & 0,08 \\
Hugo Alfvén: Midsommarvaka & 12939,50 & $-0,13$ & 0,89 \\
Modest Petrovič Musorgski: Noć na pustoj gori & 11845,00 & 1,60 & 0,11 \\
Samuel Barber: Adagio za gudače, op. 11 & 10579,00 & $-2,90$ & 0,04
\end{tabular}

(1) TABLICA 4

Rezultati Man-Whitneyevih testova za ispitivanje točnosti prepoznavanja emocije glazbenog ulomka s obzirom na njegovo poznavanje
* Glazbeni primjer poznat je gotovo svim sudionicima $(\mathrm{N}=328)$, pa nije moguće testirati efekt poznatosti.

Iz Tablice 4 vidi se da jedino $\mathrm{u}$ jednom glazbenom primjeru postoji značajan utjecaj poznatosti na prepoznavanje emocije, pri čemu su sudionici kojima je glazbeni primjer poznat u nešto većoj mjeri prepoznali dominantnu emociju straha. Budući da je razlika tek nešto iznad granice značajnosti $(p=0,04)$ te da $u$ ostalim primjerima nije utvrđena razlika, može se zaključiti da poznatost glazbenoga primjera nije važna za prepoznavanje dominantne emocije u glazbi.

Kako bi odgovorili na drugi problem istraživanja, provedena je Friedmanova ANOVA na rezultatima sudionika s obzirom na tri dominantne emocije, koja je upozorila na značajnu razliku u točnosti prepoznavanja emocija u glazbi koja je namijenjena izražavanju raznih emocija (Friedman ANOVA=17,36; $\mathrm{df}=2 ; \mathrm{p}=0,0002)$, pri čemu su najtočniji u procjeni sretnih glazbenih ulomaka $(M=1,29)$, zatim tužnih $(M=1,25)$, a najmanje točni u prepoznavanju straha kao dominantne emocije glazbenog ulomka $(\mathrm{M}=1,09)$.

Da bi odgovorili na treći problem istraživanja, izračunano je niz analiza varijance za tri zavisne varijable emocionalne kompetentnosti - sposobnost uočavanja i razumijevanja 
emocija, sposobnost izražavanja i imenovanja emocija te sposobnost upravljanja i regulacije emocija. Rezultati provedenih analiza prikazani su u Tablici 5 .

\begin{tabular}{|c|c|c|c|c|c|c|c|}
\hline & & Rezultat & $\mathrm{N}$ & M & SD & $\mathrm{F}(2,326)$ & Scheffe tes \\
\hline \multirow[t]{9}{*}{ Tuga } & Razumijevanje i uočavanje emocija & 0 & 54 & 54,89 & 6,76 & $5,16^{* *}$ & $0<2^{* *}$ \\
\hline & & 1 & 139 & 56,31 & 6,85 & & $1<2^{* *}$ \\
\hline & & 2 & 136 & 58,15 & 6,83 & & \\
\hline & Izražavanje i imenovanje emocija & 0 & 54 & 49,37 & 6,17 & $4,39^{* *}$ & $0<2^{* *}$ \\
\hline & & 1 & 139 & 51,29 & 6,91 & & \\
\hline & & 2 & 136 & 52,58 & 7,01 & & \\
\hline & Upravljanje i regulacija emocija & 0 & 54 & 63,19 & 14,07 & 0,31 & - \\
\hline & & 1 & 139 & 62,33 & 6,03 & & \\
\hline & & 2 & 136 & 62,88 & 4,96 & & \\
\hline \multirow[t]{9}{*}{ Sreća } & Razumijevanje i uočavanje emocija & 0 & 50 & 56,22 & 7,94 & $4,57^{* *}$ & $1<2^{* *}$ \\
\hline & & 1 & 133 & 55,68 & 6,43 & & \\
\hline & & 2 & 146 & 58,09 & 6,80 & & \\
\hline & Izražavanje i imenovanje emocija & 0 & 50 & 49,80 & 7,23 & 2,51 & - \\
\hline & & 1 & 133 & 51,31 & 6,61 & & \\
\hline & & 2 & 146 & 52,27 & 6,99 & & \\
\hline & Upravljanje i regulacija emocija & 0 & 50 & 60,98 & 5,83 & 2,04 & - \\
\hline & & 1 & 133 & 62,53 & 9,94 & & \\
\hline & & 2 & 146 & 63,45 & 5,19 & & \\
\hline \multirow[t]{9}{*}{ Strah } & Razumijevanje i uočavanje emocija & 0 & 76 & 54,67 & 7,65 & $7,03^{* *}$ & $0<1^{* *}$ \\
\hline & & 1 & 146 & 56,75 & 6,43 & & $0<2^{* *}$ \\
\hline & & 2 & 107 & 58,48 & 6,62 & & $1<2^{* *}$ \\
\hline & Izražavanje i imenovanje emocija & 0 & 76 & 49,63 & 7,02 & $4,16^{*}$ & $0<1^{*}$ \\
\hline & & 1 & 146 & 51,73 & 6,95 & & $0<2^{*}$ \\
\hline & & 2 & 107 & 52,54 & 6,56 & & \\
\hline & Upravljanje i regulacija emocija & 0 & 76 & 60,80 & 6,11 & $3,25^{*}$ & $0<1^{*}$ \\
\hline & & 1 & 146 & 63,07 & 9,24 & & $0<2^{*}$ \\
\hline & & 2 & 107 & 63,54 & 5,59 & & \\
\hline
\end{tabular}

${ }^{*} \mathrm{p}<0,05 ;{ }^{* *} \mathrm{p}<0,01$

(1) TABLICA 5 Rezultati jednosmiernih ANOVA za utvrđivanje razlika u rezultatima postignutima na UEK-u s obzirom na točnost prepoznavanja emocija u glazbi
Vidi se da se sudionici različitih dostignuća na upitniku prepoznavanja emocija $u$ glazbi najmanje razlikuju u emocionalnoj kompetentnosti kada je riječ o glazbenim ulomcima kojima dominira sreća. To su ujedno primjeri s najvećom točnosti procjene, na što je upozorila i spomenuta Friedmanova ANOVA. $\mathrm{S}$ druge strane, $\mathrm{u}$ glazbi dominantne emocije straha utvrđene su značajne razlike u svim komponentama emocionalne kompetentnosti između sudionika, koji su s različitom uspješnosti prepoznali emociju straha. U skupini sudionika koji su u oba glazbena primjera prepoznali i naveli da se radi upravo o strahu utvrđeni su i značajno najviši rezultati na svim podskalama Upitnika emocionalne kompetentnosti. 
(1) TABLICA 6

Koeficijenti korelacija između rezultata prepoznavania emociia $u$ glazbenim ulomcima te rezultata na pod skalama Upitnika emocionalne kompetentnosti
U trećoj skupini glazbenih primjera, gdje je dominirala tuga, pokazalo se da se sudionici koji su s različitom točnosti prepoznali dominantnu emociju razlikuju u sposobnosti uočavanja i razumijevanja emocija te $u$ sposobnosti izražavanja i imenovanja emocija, dok nije bilo razlike u sposobnosti upravljanja i regulacije emocijama.

\begin{tabular}{llll}
\hline & \multicolumn{3}{c}{ Prepoznavanje } \\
\cline { 2 - 5 } & tuge & straha & sreće \\
\hline Razumijevanje i uočavanje emocija & $0,17^{* *}$ & $0,20^{* *}$ & $0,13^{*}$ \\
Izražavanje i imenovanje emocija & $0,16^{* *}$ & $0,15^{* *}$ & $0,12^{*}$ \\
Upravljanje i regulacija emocija & 0,01 & $0,13^{*}$ & $0,11^{*}$ \\
\hline
\end{tabular}

${ }^{*} \mathrm{p}<0,05 ;{ }^{* *} \mathrm{p}<0,01$

U Tablici 6 prikazani su koeficijenti korelacija između rezultata koje su sudionici postigli na Upitniku emocionalne kompetentnosti (tri podskale) te točnosti prepoznavanja emocija u glazbenim ulomcima. Gotovo su svi koeficijenti korelacija značajni, osim povezanosti između točnosti prepoznavanja tuge i sposobnosti upravljanja i regulacije emocija.

\section{RASPRAVA}

Istraživanje odnosa između emocija i glazbe u zadnjem je desetljeću doživjelo napredak i zainteresiralo mnoge glazbenike i psihologe (Juslin i Sloboda, 2001.; Gabrielsson, 2002.; Juslin i Laukka, 2003.). Međutim, kako ističe Saarikallio (2007., 13), unatoč takvu interesu, još postoji ozbiljan manjak teorijskog razumijevanja psiholoških procesa koji su u temelju glazbenih afektivnih iskustava.

Cilj je ovoga rada bio istražiti odnos emocionalne kompetentnosti i prepoznavanja emocija u glazbi, pri čemu je zadatak sudionika bio da nakon odslušanoga glazbenog ulomka navedu dominantnu emociju koju su prepoznali u glazbenom ulomku. Rezultati istraživanja pokazali su da poznavanje glazbenog ulomka nije važno za prepoznavanje njegove dominantne emocije. Takvi rezultati mogu se objasniti postavkama Modela redundantnih znakova $u$ percepciji emocija $u$ glazbi, prema kojem se emocije u glazbi izražavaju i kulturno-specifičnim i akustičkim osobinama, poput tonaliteta, tempa i dinamike. U slučaju nepoznavanja glazbenoga djela i njegovih kulturno-specifičnih osobina, slušatelj se oslanja na akustičke osobine i na taj način percipira emocionalni sadržaj glazbe. $U$ ovom istraživanju slušatelji su u glazbi polaganoga tempa, u molu, s konstantnim rasponom visine i dinamike prepoznali emociju tuge, u glazbi brzoga tempa, s disonantnim harmonijama i velikim varijacijama dinamike i visine, prepo- 
DRUŠ. ISTRAŽ. ZAGREB GOD. 21 (2012) BR. 4 (118)

STR. $969-988$

DOBROTA, S REIĆ ERCEGÓVAC, I. ODNOS... znali su emociju straha, a u glazbi brzoga tempa, u duru, plesnih ritmova i relativno konstantnog opsega visine i dinamike, prepoznali su emociju sreće.

Takvi su rezultati u skladu s istraživanjem Balkwilla i Thompsona (1999.), koji su ispitivali mogu li slušatelji točno percipirati emocije $u$ nepoznatoj glazbi, odnosno mogu li na temelju akustičkih značajki identificirati glazbeno izražene emocije. Dobiveni rezultati također potvrđuju postavke Modela redundantnih znakova u percepciji emocija u glazbi, jer su sudionici veoma uspješno prepoznavali emocije sreće, tuge i ljutnje u nepoznatim glazbenim ulomcima. Slijedom toga zaključeno je kako su procjene emocija značajno povezane s prosudbama akustičkih glazbenih dimenzija, što potvrđuju i rezultati drugih autora (Krumhansl, 1997.; Peretz i sur., 1998.).

Rezultati su također pokazali da sudionici nisu jednako uspješni u prepoznavanju triju osnovnih emocija, pa je najviše točnih odgovora dobiveno u prepoznavanju sreće, a najmanje $u$ prepoznavanju straha. Takvi su rezultati u skladu $\mathrm{s}$ rezultatima drugih autora (Gosselin i sur., 2011.; Gašpar i sur., 2011.; Terwogt i Grinsven, 1991.; Zammuner i Petitbon, 2006.; Nawrot, 2003.). Istraživanja prepoznavanja emocija na temelju facijalne ekspresije, kao najzastupljenija među istraživanjima prepoznavanja emocija uopće, također su pokazala da je emocija sreće najprepoznatlivija od svih temeljnih emocija, bilo da je riječ o djeci (Smiley i Huttenlocher, 1989.) ili o odraslima (Montagne i sur., 2007.). Kao i u našem istraživanju, strah je s najmanjom točnošću prepoznan u glazbi i u drugim istraživanjima (Zammuner i Petitbon, 2006.; Nawrot, 2003.). Ovakve razlike $\mathrm{u}$ sposobnosti prepoznavanja raznih emocija u glazbi mogu se povezati i sa širom pretpostavkom o različitom procesiranju informacija za različite emocije, odnosno razlikama u prepoznavanju različitih emocija neovisno o modalitetu podražajnoga materijala. Naime, nekoliko je novijih istraživanja na području sposobnosti prepoznavanja emocija pokazalo da, neovisno o modalitetu podražaja (vizualni, auditivni, kombinirani), prepoznavanje emocija nije jednako za sve emocije te da postoji jasna razlika u sposobnosti prepoznavanja različitih emocija. Tome u prilog idu i rezultati ovog istraživanja, jer su koeficijenti korelacija između točnosti prepoznavanja emocija glazbenih primjera različite emocionalne obojenosti, iako značajni, relativno niski i kreću se od $\mathrm{r}=0,18$ do $r=0,32(p<0,01)$. Schlegel i sur. (2012.) utvrdili su uz upotrebu audio-vizualnih emocionalnih podražaja da je moguće razlikovati prepoznavanje pozitivnih emocija od negativnih, unutar čega se može govoriti o još specifičnijim vještinama uključenima u prepoznavanje pojedinih emocija, a MacCann i sur. (2011.) upravo su na mjerama razumijevanja emocija i upravljanja emocijama pokazali veću prikladnost modela koji 
DRUŠ. ISTRAŽ. ZAGREB GOD. 21 (2012),

BR. 4 (118),

STR. 969-988

DOBROTA, S REIĆ ERCEGÓVAC, I. ODNOS.. uzima u obzir različite emocije posebno (ljutnja, strah, tuga). Navedeni rezultati upućuju na potrebu razgraničenja emocionalne kompetentnosti, ovisno o emocijama, kako bi implikacije mjerenja emocionalne inteligencije bile što korisnije.

$\mathrm{U}$ istraživanje se krenulo od temeljne pretpostavke o značajnoj povezanosti emocionalne kompetentnosti i sposobnosti prepoznavanja emocija u glazbi. Da bismo provjerili te pretpostavke, uspoređeni su rezultati sudionika na Upitniku emocionalne kompetentnosti s obzirom na točnost prepoznavanja emocija u glazbenim ulomcima. Uočeno je kako se sudionici raznih dostignuća $u$ točnosti prepoznavanja emocija najmanje razlikuju u emocionalnoj kompetentnosti kada je riječ o glazbenim ulomcima, dominantna emocija kojih jest sreća. U glazbi u kojoj dominira emocija straha utvrđene su značajne razlike u svim komponentama emocionalne kompetentnosti između sudionika koji su s različitom uspješnosti prepoznali emociju straha. U skupini sudionika koji su u oba glazbena primjera prepoznali i naveli da je riječ o strahu utvrđeni su i značajno najviši rezultati na svim podskalama Upitnika emocionalne kompetentnosti. U trećoj skupini glazbenih primjera, gdje je dominantna emocija tuga, pokazalo se da se sudionici koji su s različitom točnosti prepoznali dominantnu emociju razlikuju u sposobnosti uočavanja i razumijevanja emocija te u sposobnosti izražavanja i imenovanja emocija, dok nije bilo razlike u sposobnosti upravljanja i regulacije emocijama. Kada tomu pridodamo rezultate koji su upozorili na značajnu povezanost između točnosti prepoznavanja emocija u glazbi te sva tri aspekta emocionalne kompetentnosti (uočavanje i razumijevanje emocija, imenovanje i izražavanje emocija te sposobnost upravljanja i regulacije emocija), može se zaključiti da rezultati ovog istraživanja potvrđuju pretpostavku o prepoznavanju emocija u glazbi kao elementu emocionalne kompetentnosti, kako to navodi Juslin (1997.). Takvi su rezultati u skladu s rezultatima Resnicowa i sur. (2004.), koji su uočili značajnu povezanost između prepoznavanja emocija $u$ glazbi i emocionalne inteligencije te su zaključili kako se prepoznavanje emocija u glazbi uglavnom oslanja na senzibilitete koji su slični onima što čine ustroj emocionalne inteligencije.

Zaključno, treba naglasiti da su rezultati ovog istraživanja potvrdili pretpostavke o značajnoj povezanosti sposobnosti prepoznavanja emocija u glazbi i rezultata na standardnim mjerama emocionalne kompetentnosti. No treba naglasiti i da su razlike $\mathrm{u}$ rezultatima dobivenima za različite emocije $\mathrm{u}$ skladu s novijim razmatranjima o specifičnosti emocionalne inteligencije, ovisno o samim emocijama. Na kraju se treba osvrnuti i na ograničenja istraživanja koja se odnose u prvom redu na odabir materijala. Riječ je o relativno malom broju 
DRUŠ. ISTRAŽ. ZAGREB GOD. 21 (2012) BR. $4(118)$

STR. $969-988$

DOBROTA, S., REIĆ ERCEGÓVAC, I. ODNOS.. glazbenih primjera koje su sudionici slušali, a i sva su djela klasične glazbe, pa se postavlja pitanje je li žanrovska ograničenost glazbenih primjera mogla utjecati na sposobnost prepoznavanja emocija. U novim bi istraživanjima bilo korisno uključiti i druge žanrovske kategorije glazbe te kontrolirati preferencije određenih glazbenih primjera prilikom analiziranja podataka o prepoznavanju emocija. Sto se tiče načina sudionikova odgovaranja u dijelu prepoznavanja emocija, u ovom je istraživanju primijenjena tehnika imenovanja dominantne emocije koju sudionik prepozna u glazbi, no ona može i izravno utjecati na rezultate. U idućim bi istraživanjima valjalo modificirati način odgovaranja, i to tako da sudionici na skalama procjene određenog raspona, posebno za svih šest temeljnih emocija, procjenjuju glazbene primjere različita emocionalnog konteksta.

\section{LITERATURA}

Balkwill, L. L. i Thompson, W. F. (1999). A cross-cultural investigation of the perception of emotion in music: Psychophysical and cultural cues. Music Perception, 17(1), 43-64. doi: 10.2307/40285811

Berlyne, D. E. (1974). The new experimental aesthetics. U D. E. Berlyne (Ur.), Studies in the new experimental aesthetics (str. 1-25). Washington, D.C.: Hemisphere Publishing.

Dillman Carpentier, F. i Potter, R. F. (2007). Effects of music on physiological arousal: Explanations into tempo and genre. Media Psychology, 10(3), 339-363.

Dolan, R. J. (2007). The human amygdala and orbital prefrontal cortex in behavioural regulation. Philosophical Transactions of the Royal Society, Biological Sciences, 362(1481), 787-799. doi:10.1098/rstb.2007. 2088

Evans, P. i Schubert, E. (2008). Relationships between express and felt emotions in music. Musicae Scientiae, 12(1), 75-99. doi: 10.1177/1029 86490801200105

Fritz, T., Friederici, A. D., Jentschke, S., Gosselin, N., Sammler, D., Peretz, I., Turner, R. i Koelsch, S. (2009). Universal recognition of three basic emotions in music. Current Biology, 19(7), 573-576. doi:10. 1016/j.cub.2009.02.058

Gabrielsson, A. (2002). Emotion perceived and emotion felt: Same or different? Musicae Scientiae, Special Issue, 2001-2002, 123-147.

Gabrielsson, A. i Juslin, P. N. (2003). Emotional expression in music. U R. J. Davidson, K. R. Scherer i H. H. Goldsmith (Ur.), Handbook of affective sciences (str. 503-534). New York: Oxford University Press.

Gašpar, T., Labor, M., Jurić, I., Dumančić, D., Ilakovac, V. i Heffer, M. (2011). Comparison of emotion recognition from facial expression and music. Collegium Antropologium, 35(1), 163-167.

Gosselin, N., Peretz, I., Hasboun, D., Baulac, M. i Samson, S. (2011). Impaired recognition of musical emotions and facial expressions following anteromedial temporal lobe excision. Cortex, 47(9), 1116-1125. doi:10.1016/j.cortex.2011.05.012 
DRUŠ. ISTRAŽ. ZAGREB GOD. 21 (2012), BR. 4 (118),

STR. 969-988

DOBROTA, S. REIĆ ERCEGÓVAC, I. ODNOS..
Jansma, M. i de Vries, B. (1995). Muziek en emotie. U E. Jansma i M. de Vries (Ur.), Muziekpsychologie (str. 204-222). Assen: Van Gorcum.

Juslin, P. N. (1997). Emotional communication in music performance: A functionalist perspective and some data. Music Perception, 14(4), 383-418. doi: 10.2307/40285731

Juslin, P. N. i Laukka, P. (2003). Communication of emotions in vocal expression and music performance: Different channels, same code? Psychological Bulletin, 129(5), 770-814. doi:10.1037/0033-2909.129.5.770

Juslin, P. N. i Sloboda, J. A. (Ur.) (2001). Music and emotion: Theory and research. New York: Oxford University Press.

Juslin, P. N. i Västfjäll, D. (2008). Emotional responses to music: The need to consider underlying mechanisms. Behavioral and Brain Sciences, 31(5), 559-621. doi:10.1017/S0140525X08005293

Kardum, I. i Gračanin, A. (2004). Emocije kao adaptacije: Pregled evolucijskih shvaćanja emocija. U J. Hrgović i D. Polšek (Ur.), Evolucija društvenosti (str. 275-293). Zagreb: Naklada Jesenski i Turk.

Keltner, D. i Ekman, P. (2003). Introduction: Expression of emotion. U R. J. Davidson, K. R. Scherer i H. H. Goldsmith (Ur.), Handbook of affective sciences (str. 411-414). New York: Oxford University Press.

Koelsch, S. (2005). Investigating emotion with music: Neuroscientific approaches. Annals of the New York Academy of Sciences, 1060, 412-418. doi:10.1196/annals.1360.034

Krumhansl, C. L. (1997). An exploratory study of musical emotions and psychophysiology. Canadian Journal of Experimental Psychology, 51(4), 336-352. doi:10.1037/1196-1961.51.4.336

Lantz, M. E., Kilgour, A. R., Nicholson, K. G. i Cuddy, L. L. (2003). Judgments of musical emotion following right hemisphere damage. Brain and Cognition, 51, 190-191.

Laukka, P. i Gabrielsson, A. (2000). Emotional expression in drumming performance. Psychology of Music, 28(2), 181-189. doi:10.1177/ 0305735600282007

Lima, C. F. i Castro, S. L. (2011). Emotion recognition in music changes across the adult life span. Cognition and Emotion, 25(4), 585-598. doi:10.1080/02699931.2010.502449

MacCann, C., Pearce, N. i Roberts, R. D. (2011). Emotional intelligence as assessed by situational judgment and emotion recognition tests: Building the nomological net. Psihologijske teme, 20(3), 393-412.

Mandler, G. (1984). Mind and body: Psychology of emotions and stress. New York: Norton.

Matsumoto, D., LeRoux, J. A., Wilson-Cohn, C., Raroque, J., Kooken, K., Ekman, P., Yrizarry, N., Loewinger, S., Uchida, H., Yee, A., Amo, L. i Goh, A. (2000). A new test to measure emotion recognition ability: Matsumoto and Ekman's Japanese and Caucasian Brief Affect Recognition Test (JACBART). Journal of Nonverbal Behavior, 24(3), 179-209. doi:10.1023/A:1006668120583

Mayer, J. D. i Salovey, P. (1997). Što je emocionalna inteligencija? U P. Salovey i D. J. Sluyter (Ur.), Emocionalni razvoj i emocionalna inteligencija, pedagoške implikacije (str. 19-54). Zagreb: Educa. 
DRUŠ. ISTRAŽ. ZAGREB GOD. 21 (2012) BR. 4 (118),

STR. $969-988$

DOBROTA, $S$ REIĆ ERCEGÓVAC, I. ODNOS..
Mohn, C., Argstatter, H. i Wilker, F. W. (2011). Perception of six basic emotions in music. Psychology of Music, 39(4), 503-517. doi:10.1177/ 0305735610378183

Montagne, B., Kessels, R. P. C., De Haan, E. H. F., Perrett, D. I. (2007). The emotion recognition task: A paradigm to measure the perception of facial emotional expressions at different intensities. Perceptual and Motor Skills, 104(2), 589-598. doi:10.2466/pms.104.2.589-598

Nawrot, E. S. (2003). The perception of emotional expression in music: Evidence from infants, children and adults. Psychology of $\mathrm{Mu}$ sic, 31(1), 75-92. doi:10.1177/0305735603031001325

Nyklicek, I., Thayer, J. F. i van Doornen, L. J. (1997). Cardiorespiratory differentiation of musically induced emotions. Journal of Psychophysiology, 11(4), 304-321.

Omar, R., Henley, S. M. D., Bartlett, W., Hailstone, J. C., Gordon, E., Sauter, D. A., Frost, C., Scott, S. K. i Warren, J. D. (2011). The structural neuroanatomy of music emotion recognition: Evidence from frontotemporal lobar degeneration. NeuroImage, 56(3), 1814-1821. doi:10.1016j.neuroimage.2011.03.002

Panksepp, J. i Bernatzky, G. (2002). Emotional sounds and the brain: The neuro-affective foundations of musical appreciation. Behavioural Processes, 60(2), 133-155. doi:10.1016/S0376-6357(02)00080-3

Pelletier, C. L. (2004). The effect of music on decreasing arousal due to stress: A meta-analysis. Journal of Music Therapy, 41(3), 192-214.

Peretz, I., Gagnon, L. i Bouchard, B. (1998). Music and emotion: Perceptual determinants, immediacy, and isolation after brain damage. Cognition, 68(2), 111-141. doi:10.1016/S0010-0277(98)00043-2

Rentfrow, P. J. i Gosling, S. D. (2003). The do re mi's of everyday life: The structure and personality correlates of music preferences. Journal of Personality and Social Psychology, 84(6), 1236-1256. doi:10.1037/ 0022-3514.84.6.1236

Resnicow, J. E., Salovey, P. i Repp, B. H. (2004). Is recognition of emotion in music performance an aspect of emotional intelligence? Music Perception: An Interdisciplinary Journal, 22(1), 145-158. doi:10. 1525/mp.2004.22.1.145

Robazza, C., Macaluso, C. i D'Urso, V. (1994). Emotional reactions to music by gender, age, and expertise. Perceptual and Motor Skills, 79(2), 939-944. doi:10.2466/pms.1994.79.2.939

Roberts, R. D., Schulze, R., O'Brien, K., MacCann, C., Reid, J. i Maul, A. (2006). Exploring the validity of the Mayer-Salovey-Caruso Emotional Intelligence Test (MSCEIT) with established emotions measures. Emotion, 6(4), 663-669. doi:10.1037/1528-3542.6.4.663

Saarikallio, S. (2007). Music as mood regulation in adolescence. Jyväskylä: University of Jyväskylä.

Scherer, K. R. (2003). Why music does not produce basic emotions: A plea for a new approach to measuring emotional effects of music. $U$ R. Bresin (Ur.), Proceedings of the Stockholm Music Acoustics Conference 2003 (str. 25-28). Stockholm: Royal Institute of Technology.

Scherer, K. R. (2000). Psychological models of emotion. U J. Borod (Ur.), The neuropsychology of emotion (str. 137-162). Oxford/New York: Oxford University Press. 
DRUŠ. ISTRAŽ. ZAGREB GOD. 21 (2012), BR. 4 (118),

STR. $969-988$

DOBROTA, S. REIĆ ERCEGÓVAC, I.: ODNOS..
Scherer, K. R. i Zentner, M. R. (2001). Emotional effects of music: Production rules. U P. N. Juslin i J. A. Sloboda (Ur.), Music and emotion: Theory and research (str. 361-392). New York: Oxford University Press.

Schlegel, K., Grandjean, D. i Scherer, K. R. (2012). Emotion recognition: Unidimensional ability or a set of modality-and emotion-specific skills? Personality and Individual Differences, 53(1), 16-21. doi:1016/ j.paid.2012.01.026

Sloboda, J. A., O'Neill, S. A. i Ivaldi, A. (2001). Functions of music in everyday life: An exploratory study using the experience sampling method. Musicae Scientiae, 5(1), 9-32.

Smiley, P. i Huttenlocher, J. (1989). Young children's acquisition of emotion concepts. U C. Saarni i P. L. Harris (Ur.), Children's understanding of emotion (str. 27-49). Cambridge, England: Cambridge University Press.

Takšić, V. (2002). Upitnici emocionalne kompetentnosti. U K. Lacković-Grgin, A. Proroković, V. Ćubela i Z. Penezić (Ur.), Zbirka psihologijskih skala i upitnika (str. 27-45). Zadar: Filozofski fakultet u Zadru.

Takšić, V., Mohorić, T. i Munjas, R. (2006). Emocionalna inteligencija: teorija, operacionalizacija, primjena i povezanost $\mathrm{s}$ pozitivnom psihologijom. Društvena istraživanja, 15(4-5), 729-752.

Terwogt, M. M. i Grinsven, F. V. (1991). Musical expression of moodstates. Psychology of Music, 19(2), 99-109. doi:10.1177/0305735691192001

Trimmer, C. G. i Cuddy, L. L. (2008). Emotional intelligence, not music training, predicts recognition of emotional speech prosody. Emotion, 8(6), 838-849. doi:10.1037/a0014080

Vink, A. (2001). Music and emotion. Living apart together: A relationship between music psychology and music therapy. Nordic Journal of Music Therapy, 10(2), 144-158.

Zammuner, V. L. i Petitbon, E. (2006). The recognition of emotional qualities expressed in music. Paper presented at 9th International Conference on Music Perception and Cognition, University of Bologna. http://www.marcocosta.it/icmpc2006/pdfs/90.pdf (30. 08. 2012.)

\section{The Relationship between Emotional Competence and Recognizing Emotions in Music}

Snježana DOBROTA, Ina REIĆ ERCEGOVAC Faculty of Philosophy, Split

The aim of this study was to investigate the relationship between recognition of emotion in music and emotional competence. The study included 329 students who first filled out the Emotional Competence Questionnaire (Takšić, 2002), and then the Assessment of Musical Excerpts Questionnaire (six instrumental musical excerpts of classical music of 
DRUŠ. ISTRAŽ. ZAGREB GOD. 21 (2012)

BR. $4(118)$

STR. 969-988

DOBROTA, S. REIĆ ERCEGÓVAC, I. ODNOS... different emotional context). The participant's task was to quote a dominant emotion which was recognized in the musical excerpt and mark whether they know that excerpt from earlier. The results showed that the familiarity of musical excerpts did not affect recognition of emotion in music, and the participants identified most accurately the emotions of happiness and sadness, while with the lowest accuracy the emotion of fear. The main hypothesis about the relationship between the recognition of emotions in music and the results on the Emotional Competence Questionnaire was confirmed. It was also established that the participants who demonstrated greater accuracy in recognizing emotions in music achieved higher scores on the Emotional Competence Questionnaire, particularly on the subscale of understanding and perception of emotion, where a significant difference for the recognition of three basic emotions was observed. Significant correlations were obtained between the results in all subscales of the Emotional Competence Questionnaire and ability of recognition of emotions in music except for the correlation between the ability of management and regulation of emotions and the ability to recognize sadness in music.

Keywords: emotions, emotional competence, music 